\title{
Inclusive practices: the role of the support teacher
}

\author{
Jesús Soldevila Pérez*, Mila Naranjo Llanos*, Joan Jordi Muntaner Guasp** \\ *Universitat de Vic-Universitat Central de Catalunya, ${ }^{* *}$ Universitat Illes Balears
}

\begin{abstract}
The purpose of this study is to describe and analyse the functions, tasks and actions of support teachers in inclusive classrooms in an ordinary school, moving from a therapeutic, integrative model to an inclusive one. Qualitative research in a longitudinal case study is presented, following two children with functional diversity over four years along three axes: the concept of inclusive education, the determination of good practices for inclusion and the role of the support teacher. The results allow us to propose different inclusive practices for support teachers, and a significant increase in the presence, participation and progress of these children in ordinary classrooms. We conclude that a conceptual change in the teaching approach of teachers can lead to the implementation of alternative teaching methods, requiring involvement of support teachers for adequate inclusion, through greater presence and participation in the ordinary educational activities of students with functional diversity, favouring their social, emotional and academic development and learning.
\end{abstract}

Keywords: inclusive education, good inclusive practice, support teacher, special education teacher, educational change.

\section{Prácticas inclusivas: el rol del docente de apoyo}

\section{RESUMEN}

El propósito de este estudio es describir y analizar las funciones, tareas y actuaciones del profesorado de apoyo en las prácticas inclusivas de aula en un centro ordinario que pasa de un modelo terapéutico e integrador a un modelo inclusivo. Para ello, se plantea una investigación cualitativa de estudio de casos longitudinal, con el seguimiento de dos niños con diversidad funcional durante cuatro años, fundamentada en tres ejes: el concepto de educación inclusiva, la determinación de buenas prácticas para la inclusión y el rol del profesor de apoyo. Los resultados han permitido definir diferentes prácticas inclusivas relacionadas con el profesor de apoyo, que han permitido un incremento significativo de la presencia, participación y progreso de estos niños en el aula ordinaria. Este trabajo nos permite concluir que un cambio conceptual en el modelo educativo de los docentes provoca la implementación de métodos didácticos alternativos, que exigen unas funciones del profesor de apoyo acordes con los planteamientos de la inclusión, que repercuten en una mayor presencia y participación de las actividades educativas ordinarias de los alumnos con diversidad funcional, favoreciendo su desarrollo y aprendizaje tanto social, emocional como académico.

Palabras Clave: educación inclusiva, buenas prácticas inclusivas, docente de apoyo, maestro educación especial, cambio educativo.

\section{Introduction.}

The aim of this article is to reflect on the need for a change in the role of the support teacher, moving from therapeutic or integrative positions towards an inclusive educational model based on the results found in a longitudinal case study carried out in an ordinary school in Catalonia. The results of this research allow us to discover and analyse the functions, tasks and actions of support teachers in inclusive classrooms.

This research is based on three key axes: the transition from integration to inclusion as a conceptual and attitudinal change necessary to modify paths to inclusion; the conceptualisation of what can be considered and defined as good inclusive practice; and the role of the support teacher in ensuring the presence, participation and progress of each one of the students in the classroom, whatever their characteristics.

\section{The concept of inclusion.}

Inclusive educational approaches are a response to discriminatory models. For this reason, international organisations like the UN and UNESCO have been working for years to ensure a fairer approach, respecting individual differences and the charsacteristics of each child. This work is based on the Declaration of Salamanca, in which the need for schools for all was manifested (OHCHR, 2013; Muntaner, 2010). 
UNESCO (1994, section 3, p.6) affirmed that schools must successfully accept and educate everyone, including children with severe disabilities. Since then, there have been many different studies of inclusive education. Authors speak of a variety of purposes for inclusive education (Ainscow 2012; Ainscow, Booth, Dyson, et al. 2006; Barton, 2009; Booth, 2011; OHCHR, 2013; Rodrigues, 2014). Muntaner (2010, p.7) indicates the following two aspects on which everyone agrees.

- "The defence of educational equity and quality for all students, without exception.

- The fight against exclusion and segregation in education".

If inclusive education has these aims, they cannot be achieved in a school that it is regulated by traditional norms (Pujolàs, 2008; Rodrigues, 2014). Inclusive schools need to innovate through ongoing analysis and revision of educational practices and processes of change.

It is not enough to focus on access to integrative practice applied over a long period of time. What is required is for all students in the classroom to participate in activities and make progress in their development (Ainscow, Booth, Dyson, et al. 2006). The incorporation of these two notions in practice marks a great difference between integration and inclusion. There is an important qualitative leap between the child that is sitting in the classroom without participating in activities, without interacting with peers and carrying out different activities to the rest of the group, often only with the support teacher or caregiver, and a child that can learn and live together with peers forming part of the group.

Presence, participation and progression also serve to review and improve practices, since to carry out inclusive (non-integrative) practices, the three items must be taken as a whole. First, one has to guarantee presence. Then one has to consider participation. Participation, as noted by Booth $(2002$, p. 2), quoted by Echeita \& Domínguez (2011), "in education implies going beyond mere access. It involves learning with others and collaborating with them. It implies active involvement with what is being learnt and taught. But participation also implies being recognised for what one is and being accepted. I participate with you when you recognise me as a person like you and you accept me as I am."

Echeita \& Domínguez (2011) add that some authors prefer to discuss participation because it has a more active connotation than the term inclusion. Furthermore, inclusion implies that others allow you to be included, which is not the case with participation, which implies reciprocal responsibility. As for progress, this refers to the fact that all students have to learn and develop from their school experiences. However, this learning does not have to be the same for all (Muntaner, 2010). Rather, it is a question of providing the maximum number of the possibilities for each person to learn according to their characteristics.

\section{Good inclusive practices.}

Good inclusive practices, according to Marchesi, Durán, Giné \& Hernández (2009), are actions that teachers carry out to achieve presence, participation and success for all students, especially those who are more vulnerable. Increasing participation in classrooms implies acceptance of difference as a natural, inevitable fact, involving many students learning together with different learning styles, previous knowledge and capacities.
Inclusive practices necessarily involve the commitment of the entire educational community. As Wehmeyer (2009, p.59) points out, it must demand "third generation inclusive practices". According to this terminology, first generation inclusion is additive in nature, that is, resources and students are added to general education classrooms. Second generation practices focus on improving the operation of classrooms in general. Third generation inclusive practices put the emphasis on the quality of the educational methods that are used. Nothing from the first or second inclusive generation is obsolete or insignificant, but it's important to focus the attention on ensuring high quality education for all students. The focus is on achieving high levels of success and participation of all in the general education classroom.

Good inclusive practices entail a series of factors, which directly influence promoting inclusive progression in the education system and which can be grouped into three blocks, as stated by Muntaner, Rosselló \& de la Iglesia (2016):

- Changes in the system

- Setting up and operating inclusive schools

- Implementing inclusive practices in the classroom

These proposals are reflected in the challenge of creating an inclusive classroom, where we have a space for all, which allows participation and exchange between all, because inclusive practice implies the creation of learning environments where all students can learn whatever their characteristics (Arnaiz, 2011). This model focuses on the students, but requires the involvement and commitment of the teachers. As Escudero (2009, p.128) states, "it is unlikely that there will be good teaching practices where there has been no relevant preparation (in values, beliefs, conceptions, methods, etc.), where it has not been possible to have access to good materials and the experiences of others, or where it has not been possible to set up teaching teams".

The implementation of good inclusive practices in the classroom should be based on specific principles and actions, among which Muntaner, Rosselló \& de la Iglesia (2016) point out the following three as most significant:

- The planning of the teaching-learning process from a perspective of diversity, considering all students and their diverse characteristics.

- The globalisation and interdisciplinarity of content as key aspects in facilitating the understanding and learning of all students, through adaptation to their abilities, interests and characteristics.

- Use of alternative teaching strategies and methods that allow the participation and learning of all students in the class, in order to reach this objective on the basis of equality of opportunities. It must look for strategies that allow us to work together on the same content, but with different kinds of learning for each child.

The consolidation of good inclusive practices requires substantial changes in the culture and decision-making of our schools and classrooms. Can be summarised this in two basic characteristics: we always work with diverse groups of students, because separate categories do not contribute anything to our work. Furthermore, we have different types of support, both human and material, that we always use in the classroom to encourage the participation and learning of all students. It is argued that the problem is not the student or their characteristics, but the opportunities and means that put at their disposal to foster their development. 


\section{Role of the support teacher.}

In relation to the third axis, the role of the support teacher is to ensure the presence, participation and progress of all students in the classroom, without exception. Ainscow (2012), citing research carried out by Takala et al. (2009) in Finland, defines three different situations based on three alternative support approaches:

- The first approach, one-to-one teaching, was considered to be effective in providing individual attention, but raised concerns for three different reasons: the pressure that could be exerted on the students receiving support, the lack of contact between these students and the rest, and the stigma of being separated from the ordinary context.

- The second approach, small group teaching, was considered favourable because of the possibility of offering support in a quiet and relaxed environment, but it also raised concerns about how some students suffered when they were removed from their peer group. They felt stigmatised and missed what was worked on in the ordinary class. Teaching in small groups did not offer the possibility of enough individual attention. To avoid this stigma and minimise difference, in research conducted in classrooms to include children with autism, Lindsay, Proulx, Scott, \& Thomson (2014) observed the benefits of having a mixture of different children with the support teacher to do some tasks. The criteria was never the level of the children: any child could receive additional help.

- The third approach, collaborative teaching with two teachers, was the modality with best results and most favoured by teachers. In this approach, more children were able to have access to support and it allowed them to remain in the classroom without missing any content.

The kind of support that is offered to the teacher is very important and has to be constantly reviewed (Sharma \& Salend, 2016), to prevent the situations that Symes \& Humphery (2012) describe in research they carried out on inclusion in the classroom of autistic children. The results of this research showed that support teachers were the principal tool for inclusion of these children, but depending on how they carried out their role they could create a negative impact. The researchers observed that:

- The children with autism that worked with a support teacher had fewer opportunities to learn in an independent way.

- The children diagnosed with autism that had a support teacher had fewer opportunities to interact with their peers and be socially included when this person was present.

- Major contact between the support teacher and the autistic children reduced the attention of the main teacher.

- The support teachers that worked with small groups were more effective than those that worked with students individually.

- The support teachers requested, apart from other things, more hours of planning together with the class teachers because they often went to class without knowing what they were expected to do.

- If the support teacher sat next to an autistic child, this child lost all the opportunities for interaction with the others, who would direct themselves to the support teacher and not directly to the child. If inclusion is to improve social abilities, and help promote knowledge and understanding between peers, it is vital that the support teacher helps facilitate this process and not act as another member of the group.

From an inclusive perspective, the support teacher changes role and moves from focusing on individual attention aimed at rehabilitation to sharing class time and responsibility with all students in the group along with the class teacher, and to sharing class time and activities between two teachers and improving the overall response to the diversity of the students. Huguet (2006) emphasises that it is necessary to agree all together on activities, groupings, spatial distribution, and so on. Secondly, it is necessary for teachers to agree on the type of participation that each will have in activities, and their involvement in the evaluation of students. Thirdly, though the scope of the activities may be broad enough to address diversity, we must take into consideration the participation of children with more learning difficulties and ensure that they receive the attention they need from their main teacher or the support teacher. Finally, the whole experience should be assessed in order to plan possible changes and improvements.

In the relationship between support teachers and class teachers, there are other aspects to take into account. Huguet (2009) points out that one of the first things that needs to be done is to be more flexible about the roles of different professionals. All too often, an exaggerated culture of specialists, and reliance on experts, generates insecurity and anxiety among class teachers. As a result, class teachers do not dare to educate or interact with special needs children, believing that only specialists have the requisite expertise. They set aside their common sense; they undervalue their capacity to respond as educators and they may even attempt to justify their conduct by referring to the condition of the children. Collaboration among professionals is needed. There should be a positive climate of confidence, in which teachers can develop capacities and attitudes such as empathy, co-responsibility and independence (Huguet, 2009).

Support teachers have to be highly trained for this task, since it is complex. It is not enough to base the approach merely on good intentions, intuition and sensitivity (Imola, 2008).

\section{Method.}

The study presented is part of a larger research project (Soldevila, 2015) whose purpose was to study more generally the process of inclusion of two children with functional diversity in an ordinary school. This article, however, focuses on the role of the support teacher.

The research studied human behaviour from the point of view of the person, their characteristics and their inner experiences (Riba, 2007). This work is based on ethnographic research (Pujadas, 2010a) and the aim of building a life story (Bertaux, 2005), using semi-structured and in-depth informal interviews with the key informants (Roca, 2010), discussion groups (Bolívar, Domingo \& Fernández, 2001; Roca, 2010) and direct observation (Riba, 2007). The methodological design was complex, since it has not been easy to give voice to two children who do not speak, in order to start out from their perspectives on knowledge, analysis and improvement of their inclusion and quality of life (Fielding, 2012; Porter, Ouvry, Morgan, \& Downs, 2001). However, one of the main priorities for this research was to be inclusive and ethical with the participants (Susinos \& Parrilla, 2013; Parrilla, 2010, Parrilla \& Sierra, 2015). Reconciling the ethnographic research 
with the research-training-action process was not easy (Cuomo, Illán \& Imola, 2010). We intended to transform the school where the two children went in an innovative way, bearing in mind that an inclusive school, as well as being a right, is also a general improvement for a school (Erten \& Savage, 2012). This research-training-action process took into account the voice of the children for reflection and rethinking improvements in inclusive classrooms and schools (Fielding, 2012; Messiou, 2014). It also focused on an advisory process with the professionals at the school, carried out for the most part in small seminars, following the steps proposed by Lago \& Onrubia (2010). Ainscow \& West (2008, p.28-29), discuss "professional research, carried out in collaboration with university students, as a means of achieving a better understanding of the educational processes".

The purpose of the study is to describe and analyse the functions, tasks and actions of support teachers in an inclusive classroom in an ordinary school. The school in this study is in the centre of Catalonia, which does not have separate special education schools. There are two children in this school that would probably be sent to a special education centre, if they lived elsewhere, because they have been diagnosed with autism, in one case, and with West Syndrome and Aicaridi Syndrome, in the second case. The criteria for the selection of these cases was that they were willing to be followed (Stake, 2010).

One of the most significant aspects of this research, from a methodological point of view, is its duration, since the children were followed intensively over a period of 4 years. Harrington, Foster, Rodger \& Ashburner (2014) affirm the value of long studies because they allow more in-depth knowledge of situations already studied.

Before to carrying out the data collection process, the relevant permits were requested. These permits included both the consent to record professionals and students as well as the commitment to protect collected data.

Data collection was carried out as follows.

\begin{tabular}{lll}
\multirow{3}{*}{ 1st year } & Instrument & Frequency \\
& Observation diary & $1-3$ times per week \\
& Informal interview & $1-3$ times per week \\
& Semi-structured interview & 6 interviews \\
& Discussion groups & 8 meetings \\
& Work in small seminars & 84 meetings \\
\hline 2nd year & Observation diary & $1-2$ times per week \\
& Informal interview & $1-2$ times per week \\
& Semi-structured interview & 8 interviews \\
& In-depth interview & 14 interviews \\
& Discussion groups & 4 meetings \\
& Work in small seminars & 112 meetings \\
\hline 3rd year & Observation diary & 1 per week \\
& Informal interview & 1 per week \\
& In depth interview & 35 interviews \\
& Discussion groups & 7 meetings \\
& Work in small seminars & 73 meetings \\
\hline 4th year & Observation diary & Once every 15 days \\
& Work in small seminars & 14 meetings \\
\hline
\end{tabular}

For analysis of the data, as proposed by Lehtomäki et al. (2014), different measurements were carried out, in order to extract themes and categories of analysis and to make a thematic and chronologi- cal record that would give meaning to such a volume of data (Pujadas, 2010b). One of the thematic blocks that emerged from the data was the importance of the role of support teachers in the process of promoting more inclusive educational practices.

\section{Results.}

The results of this research have allowed us to define different inclusive practices relating to the role of support teachers that have led to a significant increase in the presence, participation and progression of children in the classroom.

In the classrooms studied there were three changes that favoured the inclusive role of the support teacher to make possible the presence, participation and learning of the children under study. To start with, there were changes in relation to teachers' preconceptions. They moved from a rehabilitation model to a social model of disability and all the educational implications that this entails. The second item that changed was the structure of the classroom, moving from an individual structure to a cooperative one, where peers interact with each other and offer support for participation in class and the learning process. The third element that changed was classroom teaching methodology, moving from working with notebooks to learning in projects to overcome barriers to participation and learning.

Support teacher practices that were considered key aspects for inclusion in this research are described below.

- At the heart of the inclusive practices linked to the role of the support teacher is the decision of the management team to start reinforcement and support within the classroom. With this decision, the first step is taken so that the support teacher could carry out their task in the classroom. In addition, it also favours increased contact between children, avoiding the pressure that the children that previously leaving the class felt and the consequent stigmatisation (in addition to the fact that time was saved because no one had to move). Everyone stays in class without anyone missing content and everyone considers themselves members of the class, accepting diversity as a natural phenomenon.

- The support teacher works with the class teacher to take charge of all the students in the group. Ever since the children diagnosed with functional diversity were assigned to support teachers, or received support outside the classroom, form teachers were able to feel less individually responsible for them. The support teacher becomes the one that coordinates with the class teacher about what actions need to be carried out with these children, and accompanies the child in meetings with specialists and with their families. This role favours the perception that the support teacher is part of the teaching team, and fosters trust and knowledge between professionals.

- Support teachers provide support for inclusion. They offer support for the teaching task, collaborating actively in the design and development of general activities. They focus their attention on the special needs children, but also interacts with other members of class and other support teams They take control of teaching when the need arises. Thus, a greater number of students have access to their support. As there are two teachers, they find it easier to carry out alternative activities that attend to diversity and foster inclusion for all.

- The support teachers foster the autonomy of the special needs children. They offer a space for development, with- 
out managing every move, every action, school tasks and daily tasks, but rather supervising when needed. The attempt to guarantee autonomy guides actions and offers a space for development, and also ensures that the children become active in their learning. The intention is for the child to be a participant in all the activities and situations in their lives instead of a patient that needs a companion who does everything for them.

- Support teachers ensure that the child has help, whether through people, materials or activities. They motivate the children's peers to offer help when required and also guide them in how they can do this in the best possible way (how to interact with special needs children, how to show them things, etc.). Sometimes they make materials or design activities as mediators of learning.

At the beginning of this research project, the situation of the children under study was one of exclusion. Though they attended an ordinary school, most of the time they were at the Special Education Support Unit. Of the 30 hours each week in their timetable only 15 hours were marked as ordinary classroom hours. In the case of the child with autism, of these 15 hours, he only attended an average of 27 minutes, because when he entered the ordinary class - on the days that he went - he only managed to stay there for periods of 3 to 6 minutes. As soon as he entered the classroom, he began to walk from one side of the class to the other, making stereotypical movements and biting his hand, yelling, throwing pencil cases and worksheets of his peers around. He showed anxiety and discomfort, and created a situation that overwhelmed the teacher and the caretaker. In the case of the girl diagnosed with West Syndrome and Aicardi Syndrome, her presence in the ordinary class was more acceptable because she did not create so much distortion. She was in the classroom an average of 103 minutes per week, which is quite low, bearing in mind that she had to be moved in a wheelchair. The conceptions of the teachers were of little use in the classroom situation (she was there more time but went on fewer days). The occasions on which they attended their assigned classroom (each to their own) were limited in number and their situation when they were there was merely one of attendance, sitting at the back of the classroom with their support teacher, without participating and without any type of interaction with their peers.

This situation changed with the modifications described in this study. These two children went from sitting at the back of the class to sitting among a cooperative learning team, interacting with their peers and with the necessary support for their participation and learning in all activities. Their attendance increased by 570 minutes for the boy with autism and 436 minutes for the girl with West Syndrome and Aicardi Syndrome.

\section{Conclusions.}

Our conclusions based on these results are key items for the inclusion of all children. These conclusions are grouped around the three main axes describing the role of the support teacher in fostering inclusion.

a) the transition from integration to inclusion as a necessary conceptual change for modifying the role of the support teacher in regard to inclusion.

- Teachers must create learning environments not merely transfer content.
Modifying the structure and teaching methods of the classroom implies directly modifying the tasks carried out by the teacher. As long as the focus is on individuals and competition, and on transmission of content through the oral explanations of the teacher, there will be many children in the classroom that encounter insurmountable barriers to access to knowledge (Pujolàs, 2008). In addition, in these situations the support teacher can only sit next to the special needs child and listen just like the other children.

When we change the role of the class teacher and the support teacher, they become creators of learning situations and contexts, the occasions and the reasons for learning to happen (Cuomo 2007; Imola, 2010); those who accompany the children push them to think and elaborate hypotheses, introducing ideas that help children rethink their responses based on new perspectives; those who help them take a certain direction; those who offer them support, etc.

- Teach and learn content relating to inclusion for all.

In an inclusive school, each member is considered a full, valued and important member of the educational community (Stainback, Stainback \& Jackson, 1999). However, as we have seen in this research, for this to happen, it is necessary to learn inclusive values, the establishment of shared thinking and values in which equality of rights is always recognised and creating a community is the goal (Booth \& Ainscow, 2002). Therefore, it is necessary to provide space, to plan, structure and design activities for content to be learnt (Lindsay et al. 2014; Stainback, Stainback \& Jackson, 1999; Pujolàs 2008). Inclusive schools are at the same time cause and effect of learning these values. Booth (2011) proposed a set of key values in processes of inclusion.

b) the conceptualisation of what we can define as good inclusive practices.

- Carefully select teachers to work with special needs children.

UNESCO (2008, item 16) urged member states to develop mechanisms to employ suitable candidates and select qualified teachers who are sensitive to different learning needs.

The most important factors are favourable attitudes and conceptions (Barton, 2009; Boyle, Topping \& Jindal-Snape, 2013; De Boer, Piil \& Minnaert, 2011; OHCHR 2013). Management teams should have full authority to decide which year and which class group is assigned to each teacher to avoid situations of exclusion. The same is true of all teachers and specialists who will intervene in groups with special needs children.

- Change teaching methods to ensure participation, the progress of all children and respect for diversity.

We consider that schools do not identify emotional barriers to learning well enough. As we have seen in this research, cooperative learning is vital to ensuring participation of all children, but may not be sufficient in some complex cases because there are some aspects of participation that are dependent on the nature of each activity. In this research, the transformation of tasks, and teaching and learning has built on projects concerning the emotions of knowing (Cuomo, 2007; Imola 2010). Through transformation of teaching activities and tasks, all the children were able to participate and learn with and from their peers and also from their own projects. This is how support teachers can carry out their new role and significantly contribute to the implementation of activities and the experience of the children. 
- Get peers to support inclusion processes.

Stainback, Stainback \& Jackson (1999) point out that natural support relationships in which children help each other as partners and friends are as important as tasks carried out by professionals. From what we have been able to see in this research, we venture to suggest that it is vital to convert classmates into accomplices for inclusion of partners and this has to be one of the main tasks of any teacher. Peers can contribute to the class group (Villa \& Thousand, 1999) and they are content to be instruments of inclusion. In order for a child to be included in a school and its context, they have to be with their group. The teacher on their own cannot include a child; they can only work towards helping peers include them. In addition, the teacher cannot do it alone. they need the complicity of the classmates to achieve total inclusion. Peers and their support are the best resource available to a teacher.

c) the role of support teachers to ensure presence, participation and progress of all students.

- Make inclusive use of resources for support.

In order to move towards more inclusive horizons, we need to rethink special education resources that schools have and give them a more inclusive character. Resources are a controversial issue, since they can seem really necessary and, certainly, the more the better, but it all depends on what they are and how we use them. The tendency for clinical work and diagnosis fosters segregation, and segregated use of resources. Rather, resources should be at the service of inclusion, focusing directly on participation and learning of the children (Porter, 2001). Inclusive use of a resource is when the resource is adjusted to the needs of each child, affecting key aspects of the teaching and learning process, its use is planned and formalised, it has an impact on the other children and it is used in the ordinary classroom (Huguet, 2006).

- Create structures that support inclusion.

In this school, based on the analysis of the work to be carried out, the needs and the management team's commitment to following an inclusive approach, they established a special commission at the school to support the inclusion of children (Stainback, Stainback \& Jackson, 1999). The post of teaching coordinator, a rather unusual figure considered vital to this process, was created to lead the inclusion commission. Despite being a very democratic approach, it was necessary (Shields, 2010) to have someone with inclusive expertise in schools to provide help and support to those who needed it (AuCoin, 2014). This person also worked as liaison officer with the university and other advice services offering external support for innovation in schools.

\section{Bibliographic references.}

Ainscow, M. (2012). Haciendo que las escuelas sean más inclusivas: Lecciones a partir del análisis de la investigación internacional. Revista de Educación Inclusiva, 5(1), 39-49.

Ainscow, M. \& West, M. (2008). Mejorar las escuelas urbanas. Liderazgo y colaboración. Madrid: Narcea.

Ainscow, M., Booth, T., Dyson, A. Farrell, P., Frankham, J., Gallannaugh, F.,... Roy Smith, R. (2006). Improving Schools, Developing Inclusion. New York: Routledge.

Arnaiz, P. (2011). Luchando contra la exclusión: buenas prácticas y éxito escolar. Innovación educativa, (21), 23-35.

AuCoin, A. (2014). Strengthening Inclusion, Strengthening Schools. Building our future one step at a time. Revista de Educación Inclusiva, 7(2), 22-35.
Barton, L. (2009). Estudios sobre discapacidad y la búsqueda de la inclusividad: Observaciones. Revista de Educación, (349), 137-152.

Bertaux, D. (2005). Los relatos de vida. Barcelona: Bellaterra.

Bolívar, A., Domingo, J., \& Fernández, M. (2001). La investigación biográfico-narrativa en educación: Enfoque y metodología. Madrid: Muralla.

Booth, T. (2011). The name of the rose: Inclusive values into action in teacher education. Prospects, 41(3), 303-318. http://dx. doi.org/10.1007/s11125-011-9200-z

Booth, T., \& Ainscow, M. (2002). The Index for Inclusion: Developing learning and participation in schools. London: CSIE.

Boyle, C., Topping, K., \& Jindal-Snape, D. (2013). Teachers attitudes towards inclusion in high schools. Teachers and Teaching, 19(5), 527-542.

http://dx.doi.org/10.1080/13540602.2013.827361

Cuomo, N. (2007). Le emozioni, la ricerca, la pedagogía speciale. Rivista Emozione di Conoscere, (1), 1-5.

Cuomo, N., Illán, N., \& Imola, A. (2010). Las autonomías hacia una calidad de vida consciente e independiente: Algunos fundamentos teóricos para orientar las acciones. In Actas del II Congreso Iberoamericano sobre el Síndrome de Down: 29 de abril y 2 de mayo de 2010 (pp.681-705). Madrid: Real Patronato sobre Discapacidad.

de Boer, A., Pijl, S. J., \& Minnaert, A. (2011). Regular primary school teachers attitudes towards inclusive education: A review of the literature. International Journal of Inclusive Education, 15(3), 331-353.

http://dx.doi.org/10.1080/13603110903030089

Echeita, G. \& Domínguez, A. B. (2011). Educación inclusiva. Argumento, caminos y encrucijadas. Aula, (17), 23-35.

Escudero, J.M. (2009). Buenas prácticas y programas extraordinarios de atención al alumnado en riesgo de exclusión educativa. Revista de currículum y formación del profesorado, 13(3), 108-141.

Erten, O., \& Savage, R. S. (2012). Moving forward in inclusive education research. International Journal of Inclusive Education, 16(2), 221-233.

http://dx.doi.org/10.1080/13603111003777496

Fielding, M. (2012). Beyond student voice: Patterns of partnership and the demands of deep democracy. Revista de Educación, 359(2), 45-65.

Harrington, C., Foster, M., Rodger, S., \& Ashburner, J. (2014). Engaging young people with Autism Spectrum Disorder in research interviews. British Journal of Learning Disabilities, 42(2), 153-161. http://dx.doi.org/10.1111/bld.12037

Huguet, T. (2006). Aprendre junts a l'aula: Una proposta inclusiva. Barcelona: Graó.

Huguet, T. (2009). El trabajo colaborativo entre el profesorado como estrategia para la inclusión. In C. Giné (Coord.). La educación inclusiva. De la exclusión a la plena participación de todo el alumnado (pp.81-94). Barcelona: ICE, Universitat de Barcelona.

Imola, A. (2008). Le leggi verso le buone prassi dell'integrazione nell'ambito della Pedagogia Spciale. Pisa: ETS.

Imola, A. (2010). Il metodo Emozione di Conoscere di Nicola Cuomo. Rivista Emozione di Conoscere, (9), 1-28.

Lago, J. R., \& Onrubia, J. (2010). Asesoramiento psicopedagógico y mejora de la práctica educativa. Barcelona: Horsori.

Lehtomäki, E., Janhonen-Abruquah, H., Tuomi, M. T., Okkolin, M. A., Posti-Ahokas, H., \& Palojoki, P. (2014). Research to engage voices on the ground in educational development. International Journal of Educational Development, (35), 37-43. https:// doi.org/10.1016/j.ijedudev.2013.01.003 
Lindsay, S., Proulx, M., Scott, H., \& Thomson, N. (2014). Exploring teachers' strategies for including children with autism spectrum disorder in mainstream classrooms. International Journal of Inclusive Education, 18(2), 101-122. http://dx.doi.org/ $\underline{10.1080 / 13603116.2012 .758320}$

Marchesi, A., Durán, D., Giné, C., \& Hernández, L. (2009). Guía para la reflexión y valoración de prácticas inclusivas. Madrid: Organización de Estados Iberoamericanos para la educación, la ciencia y la cultura. OEI.

Messiou, K. (2014). Working with students as co-researchers in schools: A matter of inclusion. International Journal of Inclusive Education, 18(6), 601-613. http://dx.doi.org/10.1080/13603116. 2013.802028

Muntaner, J. J. (2010). De la integración a la inclusión: un nuevo modelo educativo. In P. Arnaiz, M. D. Hurtado, F. J. Soto (Coords.), 25 Años de Integración Escolar en España: Tecnología e Inclusión en el ámbito educativo, laboral y comunitario (pp.1-24). Murcia: Consejería de Educación, Formación y Empleo.

Muntaner, J.J., Rosselló, M.R., \& De la Iglesia, B. (2016). Buenas prácticas en educación inclusiva. Educatio siglo XXI, 34(1), 31 50 .

http://dx.doi.org/10.6018/j/252521

Office of the United Nations High Commissioner for Human Rights. (2013). Estudio temático sobre el derecho de las personas con discapacidad a la educación: Informe de la Oficina del Alto Comisionado de las Naciones Unidas para los Derechos Humanos. Ginebra: Consejo de Derechos Humanos.

Parrilla, M. Á. (2010). Ética para una investigación inclusiva. Revista de Educación Inclusiva, 3(1), 165-174.

Parrilla, M. Á., \& Sierra, S. (2015). Construyendo una investigación inclusiva en torno a las distintas transiciones educativas. Revista Electrónica Interuniversitaria de Formación del Profesorado, 18(1), 161-175.

http://dx.doi.org/10.6018/reifop.18.1.214381

Porter, G. L. (2001). Elements crítics per a escoles inclusives. Creant l'escola inclusiva: una perspectiva canadenca basada en 15 anys d'experiència. Suports: Revista Catalana d'Educació Especial i Atenció a la Diversitat, 5(1), 6-14.

Porter, J., Ouvry, C., Morgan, M., \& Downs, C. (2001). Interpreting the communication of people with profound and multiple learning difficulties. British Journal of Learning Disabilities, 29(1), 12-16. http://dx.doi.org/10.1046/j.14683156.2001.00083.x

Pujadas, J. J. (2010a). Trayectorias sociales e historias de vida. In J. J. Pujadas (Coord.), Etnogafía (pp. 227-255). Barcelona: UOC.

Pujadas, J. J. (2010b): La etnografía como proceso de investigación: La experiencia del trabajo de campo. In J. J. Pujadas (Coord.), Etnografía (pp. 271-311). Barcelona: UOC.
Pujolàs, P. (2008). 9 Ideas clave. El aprendizaje cooperativo. Barcelona: Graó.

Riba, C. E. (2007). La metodologia qualitativa en l'estudi del comportament. Barcelona: UOC.

Roca, J. (2010). Las entrevistas. In J. J. Pujadas (Coord.), Etnografía (pp.89-109). Barcelona: UOC.

Rodrigues, D. (2014). Os desafios da Equidade e da Inclusao na formaçao de professores. Revista de Educación Inclusiva, 7(2), 5-21.

Sharma, U., \& Salend, S. J. (2016). Teaching Assistants in Inclusive Classrooms: A Systematic Analysis of the International Research. Australian Journal of Teacher Education, 41(8), 117134. http://dx.doi.org/10.14221/ajte.2016v41n8.7

Shields, C. M. (2010). Transformative leadership: Working for equity in diverse contexts. Educational Administration Quarterly, 46(4), 558-589. http://dx.doi.org/10.1177/0013161X10375609

Soldevila, J. (2015). La inclusió escolar d'un infant amb diversitat funcional: una història de vida. (PhD. Universitat de Vic, Catalunya). Consulted from http://www.tdx.cat/handle/10803/315838

Stainback, S., Stainback, W., \& Jackson, H. J. (1999). Hacia aulas inclusivas. In S. Stainback, W. Stainback (Coords.), Aulas Inclusivas (pp.21-37). Madrid: Narcea.

Stake, R. E. (2010). Qualitative Research: Studying How Things Work. New York: The Guilford Press.

Susinos, T., \& Parrilla, Á. (2013). Investigación inclusiva en tiempos difíciles: Certezas provisionales y debates pendientes. REICE: Revista Electrónica Iberoamericana sobre Calidad, Eficacia y Cambio en Educación, 11(2), 87-98.

Symes, W., \& Humphrey, N. (2012). Including pupils with autistic spectrum disorders in the classroom: The role of teaching assistants. European Journal of Special Needs Education, 27(4), 517-532.

http://dx.doi.org/10.1080/08856257.2012.726019

UNESCO. (1994). Declaración de Salamanca. Informe final: Conferencia Mundial sobre Necesidades Educativas Especiales: Acceso y Calidad. Madrid: Ministerio de Educación y Ciencia. Secretaria de Estado de Educación.

UNESCO. (2008). La Educación Inclusiva: el camino hacia el futuro: Conclusiones y recomendaciones de la $48^{a}$ reunión de la conferencia internacional de educación (CIE). París: UNESCO.

Villa, R. A., \& Thousand J. S. (1999). La colaboración del alumno: Elemento esencial para impartir el currículo en el siglo XXI. In S. Stainback, W. Stainback (Coords.), Aulas Inclusivas (pp. 135-162). Madrid: Narcea.

Wehmeyer, M.L. (2009). Autodeterminación y la tercera generación de prácticas de inclusión. Revista de Educación, (349), 45-67. 
